Fish \& Shellfish Immunology

September 2016, Volume 56, Pages 322-329

http://dx.doi.org/10.1016/i.fsi.2016.07.021

http://archimer.ifremer.fr/doc/00346/45692/

(c) 2016 Elsevier Ltd. All rights reserved.

\title{
Flat oyster follows the apoptosis pathway to defend against the protozoan parasite Bonamia ostreae
}

\author{
Gervais Ophélie ${ }^{1}$, Chollet Bruno ${ }^{1}$, Renault Tristan ${ }^{2}$, Arzul Isabelle ${ }^{1, *}$ \\ ${ }^{1}$ Ifremer, RBE-SG2M-LGPMM, Station de La Tremblade, Avenue de Mus de Loup, F-17390, La \\ Tremblade, France \\ ${ }^{2}$ Ifremer, RBE, Centre de Nantes, Rue de l'lle d'Yeu, F-44311, Nantes, France \\ *Corresponding author : Isabelle Arzul, email address : iarzul@ifremer.fr
}

\begin{abstract}
:
The in vitro model Ostrea edulis hemocyte - Bonamia ostreae is interesting to investigate host-parasite interactions at the cellular level. Indeed, this unicellular parasite infects the flat oyster Ostrea edulis and multiplies within hemocytes, the central effectors of oyster defenses. Apoptosis is a mechanism used by many organisms to eliminate infected cells. In order to study the potential involvement of this mechanism in the oyster response to $B$. ostreae, in vitro experiments were carried out by exposing hemocytes from the naturally susceptible oyster $O$. edulis and a resistant oyster species Crassostrea gigas to live and heat-inactivated parasites. Hemocyte apoptotic response was measured using a combination of flow cytometry and microscopy analyses. Whatever the host species was, the parasite was engulfed in hemocytes and induced an increase of apoptotic parameters including intracytoplasmic calcium concentration, mitochondrial membrane potential or phosphatidyl-serine externalization as well as ultrastructural modifications. However, the parasite appears more able to infect flat oyster than cupped oyster hemocytes and the apoptotic response was more important against live than dead parasites in the natural host than in $C$. gigas. Our results suggest that $O$. edulis specifically responds to $B$. ostreae by inducing apoptosis of hemocytes.
\end{abstract}

\section{Highlights}

Apoptosis in flat and cupped oysters was investigated in the context of in vitro infections with the protozoan parasite Bonamia ostreae. Contact with live and inactivated Bonamia ostreae induces modifications of tested apoptosis parameters in both Ostrea edulis and Crassostea gigas oyster species. The apoptotic response in the flat oyster Ostrea edulis seems to be more specific to Bonamia ostreae than in the cupped oyster Crassostrea gigas. Apoptosis: an important mechanism developed by Ostrea edulis against bonamiosis.

Keywords : Apoptosis, Host-parasite interactions, Parasite, Oyster, Bonamia ostreae, Ostrea edulis 


\section{Introduction}

The flat oyster Ostrea edulis is the European endemic oyster species. In the 70's the production was dramatically reduced in relation with a combination of factors including the disease caused by the unicellular protozoan parasite Bonamia ostreae. Once the parasite is in an oyster population there is no way to eradicate it and to treat oysters. Reviving the production of $O$. edulis in an infected zone notably relies on favouring resistant or tolerant oysters and requires a better understanding of host parasite interactions, in particular mechanisms involved in the response against $B$. ostreae. Oyster defenses not only rely on the anatomical and chemical barriers including the shell and palleal organs but also mucus and cellular and soluble components of hemolymph like hemocytes, lysosomal enzymes and lectins [1]. 
In $O$. edulis/B. ostreae host/parasite model, hemocytes play a key role by being central

effectors of oyster defenses and target cell of the parasite. Despite the lack of parasite and hemocyte cultures, an in vitro experimental infection model has been developed by incubating hemocytes with parasites purified from highly infected oysters [2]. This experimental model allowed demonstrating that parasites are internalized after 30 min of contact with hemocytes [3] and are able to persist and multiply within hemocytes after $2 \mathrm{~h}$ of contact [4]. Hemocytes internalyze parasites by endocytosis but B.ostreae seem to actively contribute to its own internalization [3]. It has recently been shown that a heat shock protein 90 (HSP90) is partly involved in parasite internalization [5]. Once internalized, B.ostreae induces some modifications of hemocyte activities including decrease of reactive oxygen species (ROS) production and esterase activities [4,6]. Previous studies suggested a potential involvement of apoptosis in the response of the oyster against the parasite. Genes involved in the apoptosis pathway including Fas ligand, an inhibitor of apoptosis (IAP), Tumor necrosis factor (TNF) and apoptosis inducer factor (AIF) were found modulated in the context of experimental or field infections $[7,8]$.

Apoptosis is a highly orchestrated process developed in many organisms and plays a role in various biological processes like embryogenesis, homeostasis and particularly in defense against stress factors including pathogens by eliminating infected cells $[9,10]$. This process induces various morphological changes like chromatin condensation, membrane blebbing and in the last stages cells fragmentation into apoptotic bodies [10]. There are two main apoptotic pathways: the extrinsic pathway initiated by activation of membrane receptor like TNF receptor and Fas receptor and the intrinsic or mitochondrial pathway activated by cellular stress $[9,11]$.

In mollusc, apoptosis seems to be an important mechanism of defense against stress factors including environmental disturbances or pathogens $[1,12,13]$. In vitro studies have shown that oyster hemocyte apoptosis is increased by UV exposure [14] or by exposure to pesticides and heavy metals $[15,16]$. This mechanism leads to the death of the exposed cells. Some pathogens are able to modulate this phenomenon to favour their survivor and multiplication within hemocytes [17-19]. For example, a virulent strain of the protozoan parasite Perkinsus marinus was able to inhibit apoptosis of 
Crassostrea virginica hemocytes after few hours of in vitro contact contrary to a low virulent strain [20]. A differential apoptotic response was also reported between C. virginica and Crassotrea gigas, two species presenting different levels of susceptibility to $P$. marinus. After 3 days, percentage of apoptotic hemocytes was more important in Pacific oyster suggesting a possible activation of apoptosis as defense mechanism more important in the more resistant species [21].

As previously mentioned, genes involved in apoptosis appear to be modulated in $O$. edulis during an infection with $B$. ostreae. Considering these results, our objectives were to (i) describe more precisely the apoptotic hemocyte reaction after a contact with the parasite B.ostreae and (ii) compare the apoptotic process between hemocytes in contact with alive and heat inactivated parasites and between hemocytes from $O$. edulis and $C$. gigas, a susceptible and resistant oyster species respectively.

The combination of flow cytometry and microscopic tools recently validated to investigate apoptosis in flat oyster hemocytes [14] were used to carry out the present study.

\section{Material and methods}

\subsection{Oysters}

Adult flat oysters (> two-year-old) O. edulis were collected from Quiberon bay (Brittany, France) in October 2013 and were acclimatized in Ifremer's facilities (La Tremblade, Charente maritime, France) during two months. Pacific oysters $C$. gigas from bi-parental family produced at Ifremer's facilities in June 2013 were used for this experimentation. Oysters from both species were maintained in raceways (12000 L) supplied with a constant flow of seawater enriched in phytoplankton (Skeletonema costatum, Isochrisis galbana and Tetraselmis succica).

\subsection{Hemolymph collection}

Hemolymph was withdrawn from the hemolymphatic sinus of the adductor muscle of oysters with a 1 $\mathrm{mL}$ syringe and a needle of $0.60 \times 25 \mathrm{~mm}$. Hemolymphs were kept on ice to avoid cellular aggregation 
and were filtered at $75 \mu \mathrm{m}$ to remove debris and cell aggregates. Hemocytes were then counted using a hemocytometer and concentration adjusted at $5 \times 10^{5}$ cells. $\mathrm{mL}^{-1}$ by adding $0.22 \mu \mathrm{m}$ filtered sea water (FSW).

\subsection{Parasites}

B. ostreae was purified according to the protocol developed by [22]. Heavily infected oysters were selected by examination of gill tissue imprints using light microscopy. After homogenization of all organs except the adductor muscle, parasites were concentrated and purified by differential centrifugation on sucrose gradients. Finally, B. ostreae were suspended in FSW, counted using a hemocytometer and kept at $4^{\circ} \mathrm{C}$. Viability of parasite was tested with propidium iodide (PI) by flow cytometry according to Arzul et al. (2009). Parasite species was confirmed by RFLP PCR according to the following Standard Operating Procedure : http://www.eurlmollusc.eu/content/download/15841/236614/file/BonamiaPCR-RFLP SOP.pdf. Only B. ostreae was detected in parasite suspensions.

\subsection{In vitro contact experiments}

Hemocytes $\left(5.10^{5}\right.$ cells. $\left.\mathrm{mL}^{-1}\right)$ of $O$. edulis and $C$. gigas were incubated with live and heat inactivated parasites $\left(100^{\circ} \mathrm{C}\right.$ for $\left.15 \mathrm{~min}\right)$ at the ratio of $10: 1$ parasites per hemocyte at $15^{\circ} \mathrm{C}$. The control consisted of non-treated hemocytes suspended in FSW $\left(5.10^{5}\right.$ cells. $\left.\mathrm{mL}^{-1}\right)$. Hemocytes were analyzed after 1, 2 and 4 hours of incubation with parasites. Each condition was tested in duplicate and the whole experiment was carried out three times for flat oysters and twice for Pacific oysters.

\subsection{Light microscopy}

For each sampling time and experimental condition, $100 \mu 1$ of cell suspension were centrifuged for 1 min at $28 \mathrm{x} \mathrm{g}$ and $4{ }^{\circ} \mathrm{C}$, stained with Hemacolor ${ }^{\circledR}$ (Merk) and examined using light microscopy. 
111 Hemocyte intracytoplasmic calcium concentration, mitochondrial membrane potential $(\Delta \Psi \mathrm{m})$ and

112 phosphatidyl-serine externalisation were monitored by flow cytometry using an EPICS XL 4

113 (Beckman coulter) according to Gervais et al. (2015). Six replicates were tested for each condition.

114

115

116

117

118

119

120

121

122

123

124

125

126

127

128

129

130

131

132

133

\subsection{DNA fragmentation (TUNEL)}

DNA fragmentation was evaluated on cytocentrifuged hemocyte suspensions using the In situ Cell Death Detection Kit, POD (Roche) following Gervais et al. (2015). Six slides were observed for each condition.

\subsection{Transmission electron microscopy (TEM)}

Hemocyte suspensions $\left(1.10^{6}\right.$ cells $)$ were centrifuged at $500 \mathrm{x}$ for $8 \mathrm{~min}$ at $4^{\circ} \mathrm{C}$ and supernatant was discarded. Samples were fixed in $3 \%$ glutaraldehyde solution for 1 day at $4{ }^{\circ} \mathrm{C}$ and processed as described in Gervais et al. (2015). Two conditions were observed for both oyster species: non treated cells at $4 \mathrm{~h}$ and cells in contact with $B$. ostreae after $4 \mathrm{~h}$.

\subsection{Statistical analyses}

A non-parametric Wilcoxon test was used to estimate the effect of B. ostreae, oyster species and time on the apoptotic parameters. To compare two groups, pairwise Wilcoxon test was performed. A discriminant analysis was applied on flow cytometry parameters and percentage of "infected" cells to identify potential impact of tested conditions. To confirm separation between all the groups Wilk's lambda test was performed. Estimation of the correlation between each tested parameter was done with Spearman test. Significance was set at $\mathrm{p}<0.05\left(^{*}\right)$ for all the tests. Statistic test was performed using JMP 10.0.0 software (SAS institute Inc.).

\section{Results}

\subsection{Parasite viability}


134 Status of purified parasites was checked by flow cytometry prior to each experiment. No more than

$13524 \%$ of mortality was observed in suspensions of live parasites with an average of $17.16 \% \pm 4.31$.

136 After heat inactivation, mean parasite mortality reached $80.6 \% \pm 19.02$.

137

138

139

140

141

142

143

144

145

146

147

148

149

150

151

152

153

154

155

156

157

\subsection{Detection of parasites in hemocytes}

Whatever the oyster species and the status of $B$. ostreae (alive or inactivated) were, more than $10 \%$ of hemocytes have engulfed parasite as soon as $1 \mathrm{~h}$ of contact between hemocytes and B. ostreae (Fig. 1 A). The percentage of infected hemocytes was similar between the two species except at $1 \mathrm{~h}$ of contact, percentage was significantly lower $(\mathrm{p}<0.05)$ in $C$. gigas in contact with live parasite in comparison with $O$. edulis. The percentage of cells with live parasites was significantly higher than with dead parasites after $1 \mathrm{~h}$ of contact for $O$. edulis and after 2 and $4 \mathrm{~h}$ of contact for both oyster species $(\mathrm{p}<0.05)$. An increase of cells with internalized parasites was also observed between 1 and $2 \mathrm{~h}$ of contact for both oyster species $(\mathrm{p}<0.05)$.

The mean parasite number between $O$. edulis and $C$. gigas was significantly different at $1 \mathrm{~h}$ of contact $(\mathrm{p}<0.05)$ with live and inactivated parasites but was only different for live parasites at $2 \mathrm{~h}$ of contact (p<0.05) (Fig. 1 B). Number of B. ostreae in "infected" hemocytes was higher when parasites were alive than dead except at $1 \mathrm{~h}$ for the flat oyster and only after $4 \mathrm{~h}$ for the Pacific oyster $(\mathrm{p}<0.05)$. Mean number of parasites per "infected" hemocyte did not significantly evolve during the time of the experiment except for the both species after $4 \mathrm{~h}$ of contact with heat inactivated parasites.

\subsection{Impact of Bonamia ostreae on early apoptotic hemocyte parameters}

Early apoptotic response of hemocytes was evaluated by measuring cytoplasmic calcium concentration and $\Delta \Psi \mathrm{m}$.

The percentage of cells positive for cytoplasmic calcium was the same between controls and cells in contact with inactivated parasites whatever the oyster species was. Hemocytes in contact with live parasite showed less positive cells than with inactivated parasites as soon as $1 \mathrm{~h}$ post contact for both 

oyster species but more significantly for $O$. edulis (p<0.05) (Fig. 2). This percentage did not evolve during the time of the experiment.

Contact with inactivated and live parasites induced an increase of cells with low $\Delta \Psi \mathrm{m}$ as soon as $1 \mathrm{~h}$ post contact and during all the experiment (Fig. 3). This increase appeared higher when parasite was alive than inactivated more particularly for $O$. edulis $(\mathrm{p}<0.05)$.

\subsection{Impact of Bonamia ostreae on hemocyte plasma membrane integrity}

Hemocytes membrane integrity was evaluated by measuring phosphatidyl serine externalization. For the flat oyster, no significant difference was observed between the control and hemocytes in contact with heat inactivated parasites (Fig. 4) whereas live parasites induced a significant increase of labeled cells. In contrast, a significant increase of positive $C$. gigas hemocytes was observed in presence of live and inactivated parasites in flat oyster. No difference was observed during the time of the experiment.

\subsection{Modulation of DNA integrity of hemocytes}

Whatever the tested condition was, no more than $14 \%$ of cells were labeled (Fig. 5). The only significant difference was observed for hemocytes from flat oysters in contact with live parasites.

\subsection{Discriminant analysis}

A discriminant analysis was carried out to determine if apoptotic parameters tested in flow cytometry and TUNEL allowed discriminating tested conditions. To confirm group discrimination, a Wilk's lambda test was carried out and showed that groups were clustered by species and tested experimental condition $(\mathrm{p}<0.001)$ but not by the time. Three groups could be identified: (i) a first group included control of both oyster species; (ii) a second group included hemocytes in contact with inactivated parasites for both oyster species and in contact with live parasites for C. gigas only;(iii) a last group included only hemocytes of $O$. edulis after contact with live parasites (Fig. 6). Parameters "cytoplasmic calcium", "mitochondrial membrane potential" and "externalization of phosphatidyl 
serine" appeared correlated whereas "DNA fragmentation" was not correlated with the other tested parameters.

\subsection{Correlation test}

Potential correlation between parameters was tested using a Spearman test. A positive strong correlation was observed between the percentage of "infected" hemocytes and $\Delta \Psi \mathrm{m} /$ externalization of phosphatidyl serine and between $\Delta \Psi \mathrm{m}$ and the externalization of phosphatidyl serine (Fig. 7). A negative strong correlation was found between the intracytoplasmic calcium concentration and the percentage of "infected" hemocytes, $\Delta \Psi \mathrm{m}$ and the externalization of phosphatidyl serine. In contrast, DNA fragmentation (measured using TUNEL) was not correlated with the other tested parameters.

\subsection{Morphological changes}

Similarly to results obtained by flow cytometry, less apoptotic cells were observed by transmission electron microscopy in the controls for both oyster species (Table1, Fig. 8A, D). Parasites were noticed within hemocytes after $4 \mathrm{~h}$ of contact whatever the oyster species was (Fig. 8C, F). Apoptotic hemocytes were observed among the cells which have internalized parasites but also among the "noninfected" ones for both oyster species (Fig. 8B-C, E-F). Apoptotic modifications included chromatin condensation (Fig. 8B-C, E-F), detachment of the nuclear membrane (Fig. 8B-C) and vacuolization of the cytoplasm (Fig. 8B).

\section{Discussion}

Apoptosis is a cellular mechanism that leads to the cell death $[9,10]$. This pathway is universal among metazoan organisms and related pathways have also been described in unicellular organisms like Trypanosoma spp., Plasmodium spp., Toxoplasma spp. and Leishmania spp. [24-26]. It is a mechanism that allows eliminating damaged cells or cells infected with pathogens. However, some pathogens are able to modulate apoptosis of cells involved in immunity to evade host immune defense 
or to inhibit apoptosis of the cells they infect in order to survive and multiply within the target cells

Few studies have been carried out to investigate apoptosis in molluscs in response to diseases. Most of

these works focused on the parasite P. marinus in C. virginica $[20,21,28]$. However, the specificity of this response has never been questioned.

Previous studies have suggested the potential involvement of apoptosis in the response of the flat oyster $O$. edulis against an infection with the protozoan parasite B. ostreae [8]. This hypothesis was supported by a modulation of the expression of oyster genes involved in the apoptosis pathway including IAP and Fas ligand in presence of the parasite [8]. In order to confirm this molecular evidence, we have investigated the apoptotic response of hemocytes exposed to parasites in vitro by combining microscopic and cellular tools previously developed [14]. Additionally, the specificity of this response has been tested by comparing the response of the susceptible species $O$. edulis with the response of a species considered as resistant, C. gigas [29,30]. In vitro experimental infection showed that as soon as $1 \mathrm{~h}$ of contact some heat inactivated and live parasites were internalized by hemocytes of both oyster species. After 2 hours, "infected" hemocytes were more abundant when parasites were alive than heat inactivated. Generally, more "infected" hemocytes were observed when cells were in contact with live parasites than heat inactivated parasites for $O$. edulis than $C$. gigas. These results are in agreement with previous studies showing that $B$. ostreae was involved in its own internalization. Indeed, B. ostreae treatment consisting in blocking actin and HSP90 drastically reduced the percentage of "infected" cells $[3,5,6]$.

In flat oyster hemocytes, contact with live parasites increased apoptosis as revealed by a decrease of cytoplasmic calcium and mitochondrial membrane potential and an increase of phosphatidyl serine externalization, DNA fragmentation and ultrastructure alterations. These modifications appeared significantly higher when parasites were alive compared to heat inactivated parasites which suggests that live B. ostreae actively induces hemocyte apoptosis. Studies on P. marinus showed that inactivation of the parasite did not modify early apoptotic response of hemocytes in $C$. virginica [20]. 
TEM examination showed that apoptosis in hemocytes in contact with parasites occurred in "infected" cells but also in "non-infected" hemocytes. This response can be triggered by the parasite directly or by infected cells. Apoptosis might allow the oysters to decrease the number of available host cells and thus the capacity of the parasite to develop and multiply. If apoptosis can be considered as beneficial for the oyster it can also contribute to affect the oyster itself by depleting the population of hemocytes. This early specific activation of apoptosis suggests that there is a specific interaction between hemocytes of $O$. edulis and B. ostreae. This interaction could rely on the recognition and binding of $B$. ostreae with an hemocyte receptor activating the apoptosis pathway. A previous study has shown that the galectin, Oe-Gal, can interact with B. ostreae and plays a role in the internalization of the parasite (Prado-Alvarez, Unpublished). Galectins can modulate cell apoptosis [31-34]. During infection, they can inhibit parasite replication and commit cells to death by apoptosis [33-35].

Basal apoptotic rate in control condition was the same in both oyster species. Both alive and heat treated parasites induced an increase of hemocytes apoptosis in flat oyster and cupper oysters. However, difference could be noticed between both oyster species: for example, percentage of cells with intracytoplasmic calcium decreased more significantly in presence of live parasite in $O$. edulis than in $C$. gigas. These results suggest that the parasite is more able to actively induce its own internalization by modulating cytoskeleton in hemocytes from $O$. edulis than in C. gigas. Similarly, pathogens like Trypanosoma cruzi are known to favour their entry in the host cells by modulating host cytoskeleton through a change of intracellular calcium [36]. These results are also supported by the higher percentage of infected hemocytes for $O$. edulis compared to C. gigas.

Hemocyte $\Delta \Psi \mathrm{m}$ was enhanced by the contact with parasites whatever the oyster species and the parasite status were. However, this increase was significantly higher in $O$. edulis when the parasite was alive. Moreover, hemocyte membrane integrity appeared only altered in flat oyster when $B$. ostreae was alive whereas in $C$. gigas it was modified similarly in presence of live and dead parasites. Finally, DNA fragmentation was significantly increased only in flat oyster hemocytes after contact with live B. ostreae. Thus, contrary to results observed in $O$. edulis, less difference was found in $C$. gigas between hemocytes in contact with alive and heat-treated parasites suggesting that defense 
strategy against the parasite is different in both oyster species. Incidentally, $C$. gigas has never been detected infected with $B$. ostreae implying that confrontation between hemocytes and B. ostreae should rarely occur.

Combining different cellular tools allowed us discriminating between tested conditions. Correlations observed between cytoplasmic calcium concentration, mitochondrial membrane potential and externalization of phosphatidyl serine suggest that it not necessary to measure all these parameters to monitor apoptosis in hemocyte in response to B. ostreae. However, using complementary approaches including cytometry and microscopy allows describing more widely early modifications induced by an in vitro infection with $B$. ostreae. For the first time we showed that $B$. ostreae in vitro infection induces apoptosis not only in hemocytes of flat oyster $O$. edulis but also of $C$. gigas. However, $B$. ostreae appears more efficient to infect $O$. edulis than $C$. gigas hemocytes and the flat oyster seems to respond more specifically to live parasites by increasing hemocyte apoptosis than $C$. gigas. Although hemocytes of $C$. gigas were less infected, percentages of apoptotic hemocytes were higher than in $O$. edulis. This result might partly explain the resistance of $C$. gigas against B. ostreae.

Our experiments were probably not long enough to observe a potential modulation of this response by the parasite itself. Indeed, previous studies carried out in vitro showed that hemocyte apoptosis induced by different $P$. marinus strains was inhibited after 5 hour of contact [20]. Complementary in vivo infection would also be helpful to draw an integrative picture of this mechanism in response to an infection in molluscs.

\section{Acknowledgements}

The authors wish to thank all members of the staff of the Ifremer hatchery in La Tremblade for their technical assistance for the maintenance of oysters in Ifremer La Tremblade, France. We gratefully acknowledge L. Degremont for his involvement in the production of the Pacific oyster family used in the present study. We thank A. Langlade for supplying flat oysters from Quiberon. This work was supported by Ifremer and the Région of Poitou Charentes, France. 
[1] I. Sokolova, Apoptosis in molluscan immune defense, Invertebr. Surviv. J. (2009) 49-58.

[2] C. Mourton, V. Boulo, D. Chagot, D. Hervio, E. Bachere, E. Mialhe, H. Grizel, Interactions between Bonamia ostreae (Protozoa: Ascetospora) and hemocytes of Ostrea edulis and Crassostrea gigas (Mollusca: Bivalvia): in vitro system establishment, J. Invertebr. Pathol. 59 (1992) 235-240. doi:10.1016/0022-2011(92)90127-P.

[3] D. Chagot, V. Boulo, D. Hervio, E. Mialhe, E. Bachere, C. Mourton, H. Grizel, Interactions between Bonamia ostreae (Protozoa: Ascetospora) and hemocytes of Ostrea edulis and Crassostrea gigas (Mollusca: Bivalvia): Entry mechanisms, J. Invertebr. Pathol. 59 (1992) 241249. doi:10.1016/0022-2011(92)90128-Q.

[4] B. Morga, T. Renault, N. Faury, B. Chollet, I. Arzul, Cellular and molecular responses of haemocytes from Ostrea edulis during in vitro infection by the parasite Bonamia ostreae, Int. J. Parasitol. 41 (2011) 755-764. doi:10.1016/j.ijpara.2011.01.013.

[5] M. Prado-Alvarez, B. Chollet, Y. Couraleau, B. Morga, I. Arzul, Heat Shock Protein 90 of Bonamia ostreae: Characterization and Possible Correlation with Infection of the Flat Oyster, Ostrea edulis, J. Eukaryot. Microbiol. 60 (2013) 257-266. doi:10.1111/jeu.12031.

[6] B. Morga, I. Arzul, B. Chollet, T. Renault, Infection with the protozoan parasite Bonamia ostreae modifies in vitro haemocyte activities of flat oyster Ostrea edulis, Fish Shellfish Immunol. 26 (2009) 836-842. doi:10.1016/j.fsi.2009.03.018.

[7] L. Martín-Gómez, A. Villalba, M.J. Carballal, E. Abollo, Molecular characterisation of TNF, AIF, dermatopontin and VAMP genes of the flat oyster Ostrea edulis and analysis of their modulation by diseases, Gene. 533 (2014) 208-217. doi:10.1016/j.gene.2013.09.085.

[8] B. Morga, T. Renault, N. Faury, I. Arzul, New insights in flat oyster Ostrea edulis resistance against the parasite Bonamia ostreae, Fish Shellfish Immunol. 32 (2012) 958-968. doi:10.1016/j.fsi.2012.01.026.

[9] C. Assunção Guimarães, R. Linden, Programmed cell deaths. Apoptosis and alternative deathstyles, Eur. J. Biochem. FEBS. 271 (2004) 1638-1650. doi:10.1111/j.14321033.2004.04084.x.

[10] G. Häcker, The morphology of apoptosis, Cell Tissue Res. 301 (2000) 5-17.

[11] M.O. Hengartner, The biochemistry of apoptosis, Nature. 407 (2000) 770-776. doi:10.1038/35037710.

[12] T. Kiss, Apoptosis and its functional significance in molluscs, Apoptosis Int. J. Program. Cell Death. 15 (2010) 313-321. doi:10.1007/s10495-009-0446-3.

[13] A. Romero, B. Novoa, A. Figueras, The complexity of apoptotic cell death in mollusks: An update, Fish Shellfish Immunol. 46 (2015) 79-87. doi:10.1016/j.fsi.2015.03.038.

[14] O. Gervais, T. Renault, I. Arzul, Induction of apoptosis by UV in the flat oyster, Ostrea edulis, Fish Shellfish Immunol. 46 (2015) 232-242. doi:10.1016/j.fsi.2015.05.046.

[15] J. Russo, L. Madec, Haemocyte apoptosis as a general cellular immune response of the snail, Lymnaea stagnalis, to a toxicant, Cell Tissue Res. 328 (2007) 431-441. doi:10.1007/s00441006-0353-7.

[16] I.M. Sokolova, S. Evans, F.M. Hughes, Cadmium-induced apoptosis in oyster hemocytes involves disturbance of cellular energy balance but no mitochondrial permeability transition, $\mathrm{J}$. Exp. Biol. 207 (2004) 3369-3380. doi:10.1242/jeb.01152.

[17] J.C. Carmen, A.P. Sinai, Suicide prevention: disruption of apoptotic pathways by protozoan parasites, Mol. Microbiol. 64 (2007) 904-916. doi:10.1111/j.1365-2958.2007.05714.x.

[18] C.G.K. Lüder, U. Gross, M.F. Lopes, Intracellular protozoan parasites and apoptosis: diverse strategies to modulate parasite-host interactions, Trends Parasitol. 17 (2001) 480-486. doi:10.1016/S1471-4922(01)02016-5.

[19] S. Picot, Apoptose et mort cellulaire programmée, un nouveau paradigme de la relation hôte/parasite, Médecine Trop. 66 (2006) 111-117. 
[20] F.M. Hughes, B. Foster, S. Grewal, I.M. Sokolova, Apoptosis as a host defense mechanism in Crassostrea virginica and its modulation by Perkinsus marinus, Fish Shellfish Immunol. 29 (2010) 247-257. doi:10.1016/j.fsi.2010.03.003.

[21] M. Goedken, B. Morsey, I. Sunila, S. De Guise, Immunomodulation of Crassostrea gigas and Crassostreae virginica cellular defense mechanisms by Perkinsus marinus, J. Shellfish Res. 24 (2005) 487-496. doi:10.2983/0730-8000(2005)24[487:IOCGAC]2.0.CO;2.

[22] E. Mialhe, E. Bachère, D. Chagot, H. Grizel, Isolation and purification of the protozoan Bonamia ostreae (Pichon et al. 1980), a parasite affecting the flat oyster Ostrea edulis, L. Aquaculture. 71 (1988) 293-299.

[23] I. Arzul, B. Gagnaire, C. Bond, B. Chollet, B. Morga, S. Ferrand, M. Robert, T. Renault, Effects of temperature and salinity on the survival of Bonamia ostreae, a parasite infecting flat oysters Ostrea edulis, Dis. Aquat. Organ. 85 (2009) 67-75. doi:10.3354/dao02047.

[24] A. Debrabant, N. Lee, S. Bertholet, R. Duncan, H.L. Nakhasi, Programmed cell death in trypanosomatids and other unicellular organisms, Int. J. Parasitol. 33 (2003) 257-267.

[25] M. Deponte, Programmed cell death in protists, Biochim. Biophys. Acta BBA - Mol. Cell Res. 1783 (2008) 1396-1405. doi:10.1016/j.bbamcr.2008.01.018.

[26] D. Smirlis, M. Duszenko, A.J. Ruiz, E. Scoulica, P. Bastien, N. Fasel, K. Soteriadou, Targeting essential pathways in trypanosomatids gives insights into protozoan mechanisms of cell death, Parasit. Vectors. 3 (2010) 107. doi:10.1186/1756-3305-3-107.

[27] W.R. Proto, G.H. Coombs, J.C. Mottram, Cell death in parasitic protozoa: regulated or incidental?, Nat. Rev. Microbiol. 11 (2013) 58-66. doi:10.1038/nrmicro2929.

[28] I. Sunila, J. LaBanca, Apoptosis in the pathogenesis of infectious diseases of the eastern oyster Crassostrea virginica, Dis. Aquat. Organ. 56 (2003) 163-170. doi:10.3354/dao056163.

[29] S.A. Lynch, E. Abollo, A. Ramilo, A. Cao, S.C. Culloty, A. Villalba, Observations raise the question if the Pacific oyster, Crassostrea gigas, can act as either a carrier or a reservoir for Bonamia ostreae or Bonamia exitiosa, Parasitology. 137 (2010) 1515-1526. doi:10.1017/S0031182010000326.

[30] T. Renault, N. Cochennec, H. Grizel, Bonamia ostreae, parasite of the European flat oyster, Ostrea edulis, does not experimentally infect the Japanese oyster, Crassostrea gigas, Bull. Eur. Assoc. Fish Pathol. 15 (1995) 78-80.

[31] G.R. Vasta, Roles of galectins in infection, Nat. Rev. Microbiol. 7 (2009) 424-438. doi:10.1038/nrmicro2146.

[32] G.R. Vasta, Galectins as pattern recognition receptors: structure, function, and evolution, Adv. Exp. Med. Biol. 946 (2012) 21-36. doi:10.1007/978-1-4614-0106-3_2.

[33] R.C. Davicino, R.J. Eliçabe, M.S. Di Genaro, G.A. Rabinovich, Coupling pathogen recognition to innate immunity through glycan-dependent mechanisms, Int. Immunopharmacol. 11 (2011) 1457-1463. doi:10.1016/j.intimp.2011.05.002.

[34] G.A. Rabinovich, A. Gruppi, Galectins as immunoregulators during infectious processes: from microbial invasion to the resolution of the disease, Parasite Immunol. 27 (2005) 103-114. doi:10.1111/j.1365-3024.2005.00749.x.

[35] E. Zúñiga, A. Gruppi, J. Hirabayashi, K.I. Kasai, G.A. Rabinovich, Regulated expression and effect of galectin-1 on Trypanosoma cruzi-infected macrophages: modulation of microbicidal activity and survival, Infect. Immun. 69 (2001) 6804-6812. doi:10.1128/IAI.69.11.68046812.2001.

[36] C.L. Epting, B.M. Coates, D.M. Engman, Molecular mechanisms of host cell invasion by Trypanosoma cruzi, Exp. Parasitol. 126 (2010) 283-291. doi:10.1016/j.exppara.2010.06.023. 
Figure 1: Percentage of hemocytes with internalized live or inactivated Bonamia ostreae in Ostrea edulis and Crassostrea gigas during the time (A). Number of parasites per hemocyte of $O$. edulis and C. gigas (B). Boi: B. ostreae inactivated, Bo: B. ostreae. Results represent the mean $\pm \mathrm{SD}$. a: significant difference with inactivated parasites $(\mathrm{p}<0.05)$, b: significant difference with flat oysters $(\mathrm{p}<0.05) \mathrm{c}$ : significant difference with $1 \mathrm{~h}(\mathrm{p}<0.05)$, d: significant difference with $2 \mathrm{~h}(\mathrm{p}<0.05)$.

Figure 2: Modulation of cytoplasmic calcium concentration in hemocytes of Ostrea edulis and Crassostrea gigas following Bonamia ostreae exposure. Percentage of labeled hemocytes with cytoplasmic calcium concentration depending on the oyster species and the exposure to B. ostreae during the time. Results represent the mean $\pm \mathrm{SD}$ of three experiments. control: non exposed, Boi: $B$. ostreae inactivated, Bo: B. ostreae. a: significant difference with control $(\mathrm{p}<0.05)$, b: significant difference with $B$. ostreae inactivated ( $<<0.05)$, c: significant difference with $O$. edulis $(\mathrm{p}<0.05)$.

Figure 3: Modulation of mitochondrial membrane potential ( $\Delta \Psi \mathrm{m})$ in hemocytes of Ostrea edulis and Crassostrea gigas following Bonamia ostreae exposure. Percentage of labeled hemocytes with low $\Delta \Psi \mathrm{m}$ in function of the oyster species and exposure or not to $B$. ostreae during the time. Results represent the mean $\pm \mathrm{SD}$ of three experiments. control: non exposed, Boi: $B$. ostreae inactivated, Bo: $B$. ostreae. a: significant difference with control $(\mathrm{p}<0.05)$, b: significant difference with $B$. ostreae inactivated $(\mathrm{p}<0.05)$, c: significant difference with O. edulis $(\mathrm{p}<0.05)$.

Figure 4: Modulation of plasma membrane integrity in hemocytes of Ostrea edulis and Crassostrea gigas following Bonamia ostreae exposure. Percentage of AnnexinV positive and PI negative hemocytes depending on the oyster species and the exposure to B. ostreae during the time. Results represent the mean $\pm \mathrm{SD}$ of three experiments. control: non exposed, Boi: B. ostreae inactivated, Bo: live $B$. ostreae. a: significant difference with control $(\mathrm{p}<0.05)$, b: significant difference with $B$. ostreae inactivated ( $<<0.05)$, c: significant difference with $O$. edulis $(\mathrm{p}<0.05)$.

Figure 5: Modulation of DNA integrity of Ostrea edulis and Crassostrea gigas following Bonamia ostreae exposure. Percentage of TUNEL positive hemocytes in function of the oyster species and exposure or not to $B$. ostreae during the time. Results represent the mean $\pm \mathrm{SD}$ of three experiments. control: non exposed, Boi: B. ostreae inactivated, Bo: B. ostreae. a: significant difference with $B$. ostreae inactivated $(\mathrm{p}<0.05)$, b: significant difference with $1 \mathrm{~h}(\mathrm{p}<0.05)$.

Figure 6: Discriminant analysis of flow cytometry parameters depending on tested conditions. Oe: Ostrea edulis represented in shade of blue, Cg: Crassostrea gigas represented in shade of grey. Boi: hemocyte in contact of inactivated Bonamia ostreae represented by small dot line, Bo: hemocyte in contact of live B. ostreae represented by big dot line. 1, 2 and 4: time of the experiment post contact with B. ostreae, the darkest shade represent lower time and the lightest shade represent the longest contact time. 
419 Figure 7: Correlation between tested parameters. Negative and positive correlations are shown in

420 blue and red respectively.

421 Figure 8: Morphological changes observed after 4h of contact with Bonamia ostreae by

422 transmission electron microscopy. Ostrea edulis: (A) control cell, (B) apoptotic hemocyte without $B$.

423 ostreae internalization, (C) apoptotic hemocyte with B. ostreae internalization. Crassostrea gigas: (D)

424 control cell, (E) apoptotic hemocyte without internalization of B. ostreae, (F) apoptotic hemocyte with

425 B. ostreae internalization. Arrowheads: B. ostreae.

426 


\section{ACCEPTED MANUSCRIPT}

427 Table 1. Percentages of different cells status among hemocytes of Ostrea edulis or Crassostrea gigas 428 oysters after $4 \mathrm{~h}$ of contact or not with Bonamia ostreae.

\begin{tabular}{|c|c|c|c|c|c|}
\hline & & $\begin{array}{l}\% \text { of normal } \\
\text { cells }\end{array}$ & $\begin{array}{l}\% \text { of apoptotic } \\
\text { cells }\end{array}$ & $\begin{array}{l}\% \text { of secondary } \\
\text { necrotic cells }\end{array}$ & $\begin{array}{l}\% \text { of necrotic } \\
\text { cells }\end{array}$ \\
\hline \multirow[t]{2}{*}{ O. edulis } & Control $(n=59)$ & 61 & 27.1 & 3.4 & 8.1 \\
\hline & $\begin{array}{ll}\text { B. } & \text { ostreae } \\
(\mathrm{n}=55) & \end{array}$ & 38.18 & 50.91 & 3.64 & 7.27 \\
\hline \multirow[t]{2}{*}{ C. gigas } & Control $(n=52)$ & 88.46 & 11.54 & 0 & 0 \\
\hline & $\begin{array}{ll}\text { B. } & \text { ostreae } \\
(\mathrm{n}=45) & \end{array}$ & 35.56 & 57.78 & 0 & 6.67 \\
\hline
\end{tabular}

429 


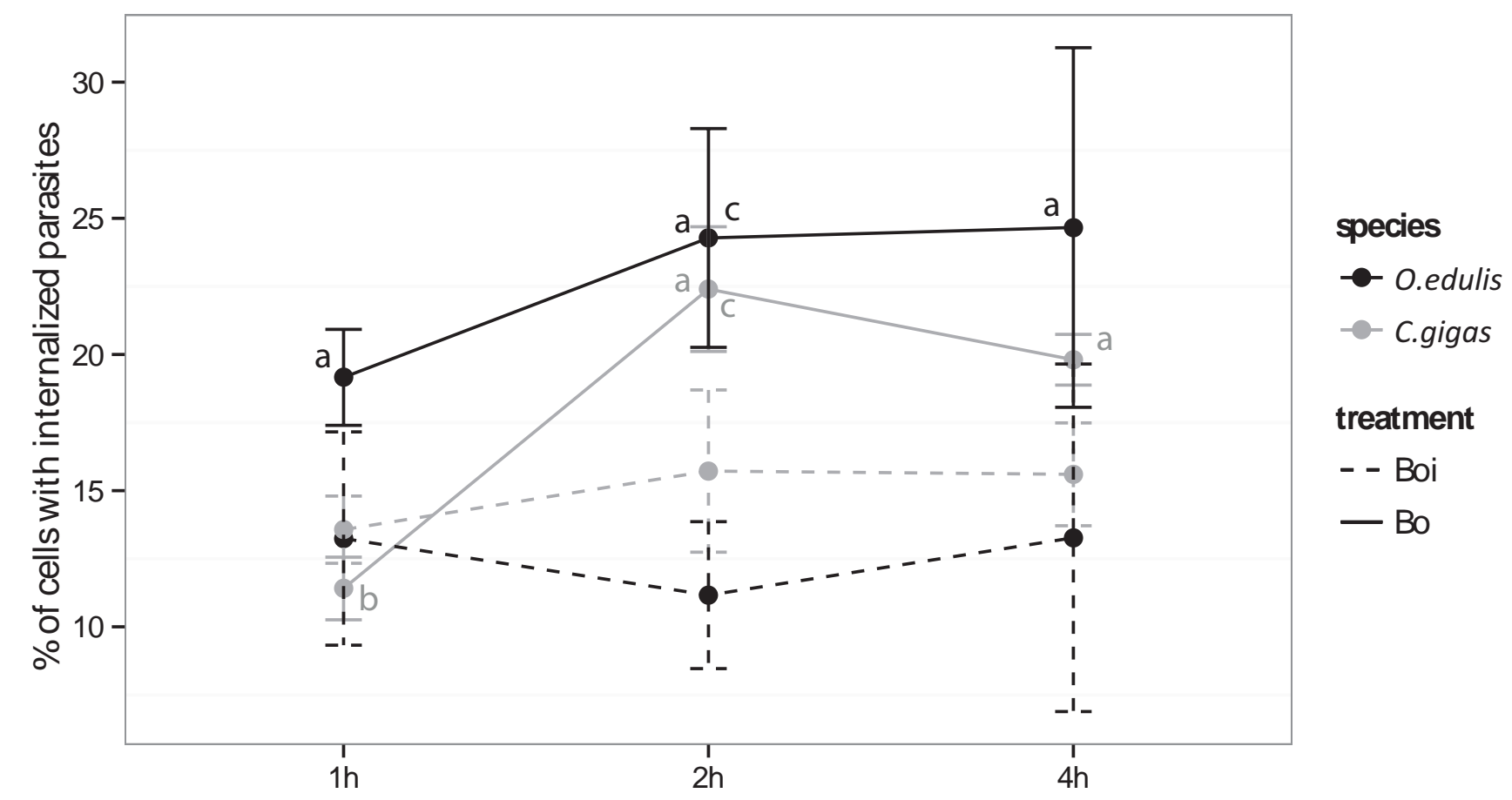




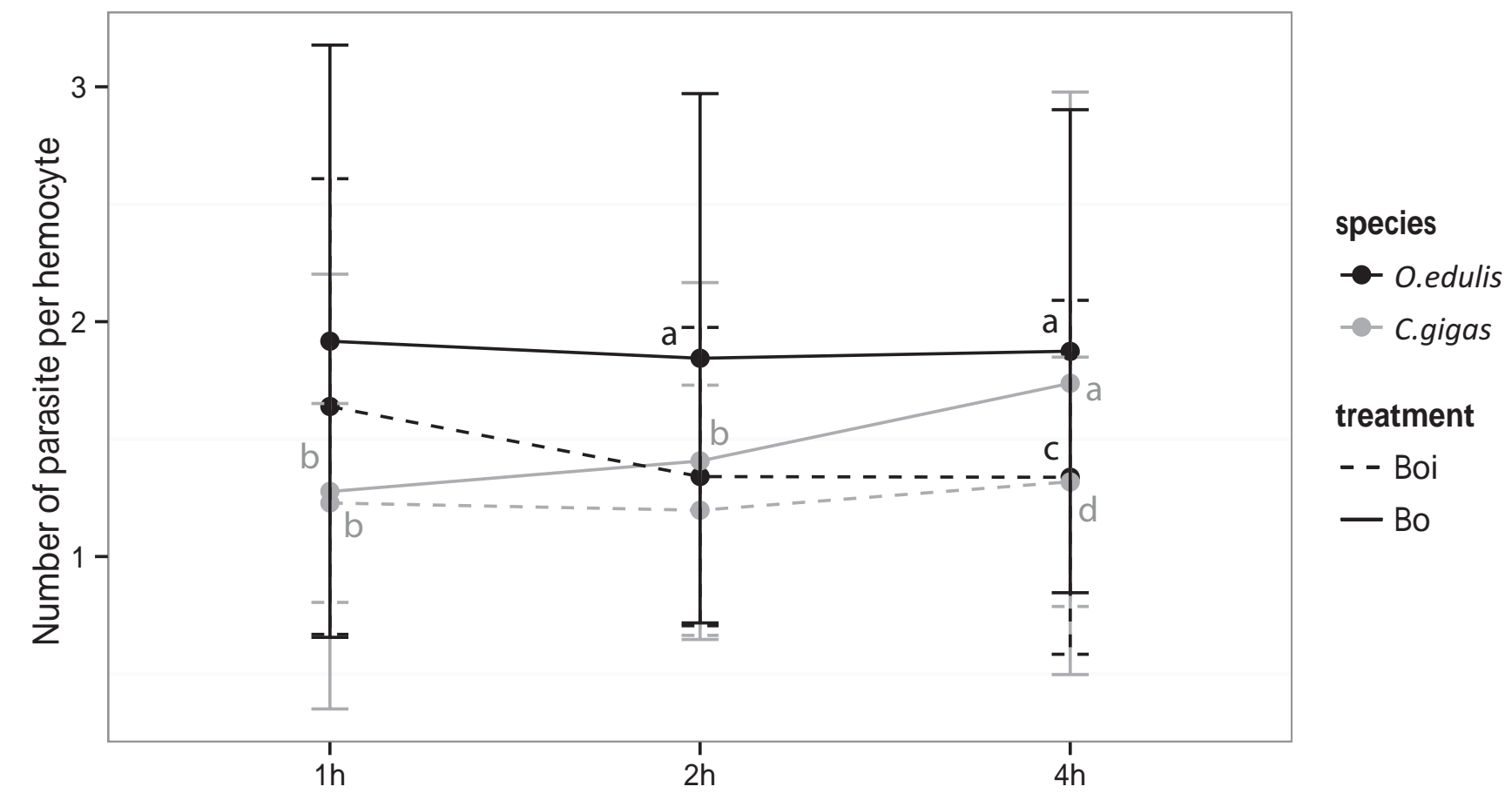




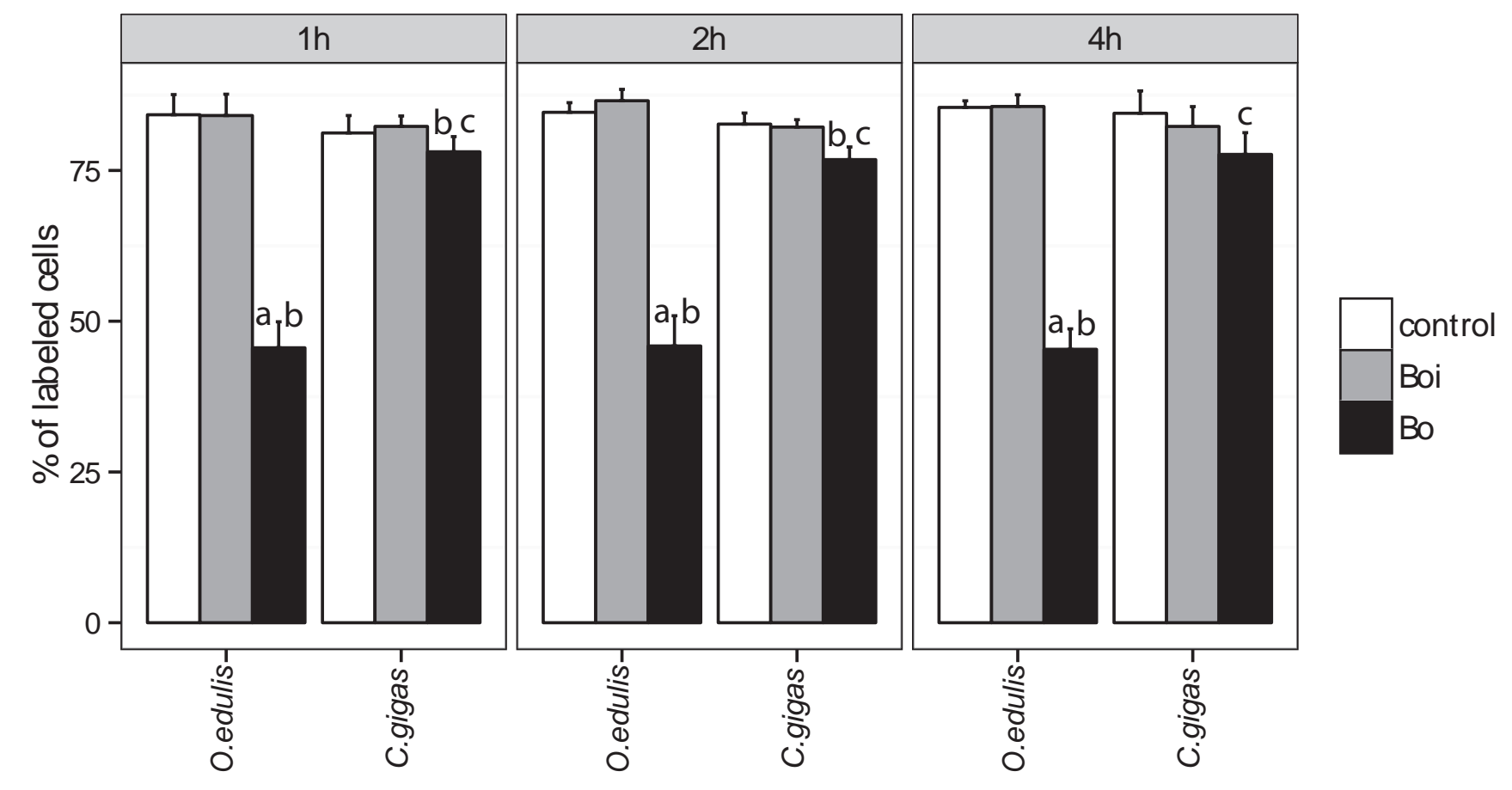




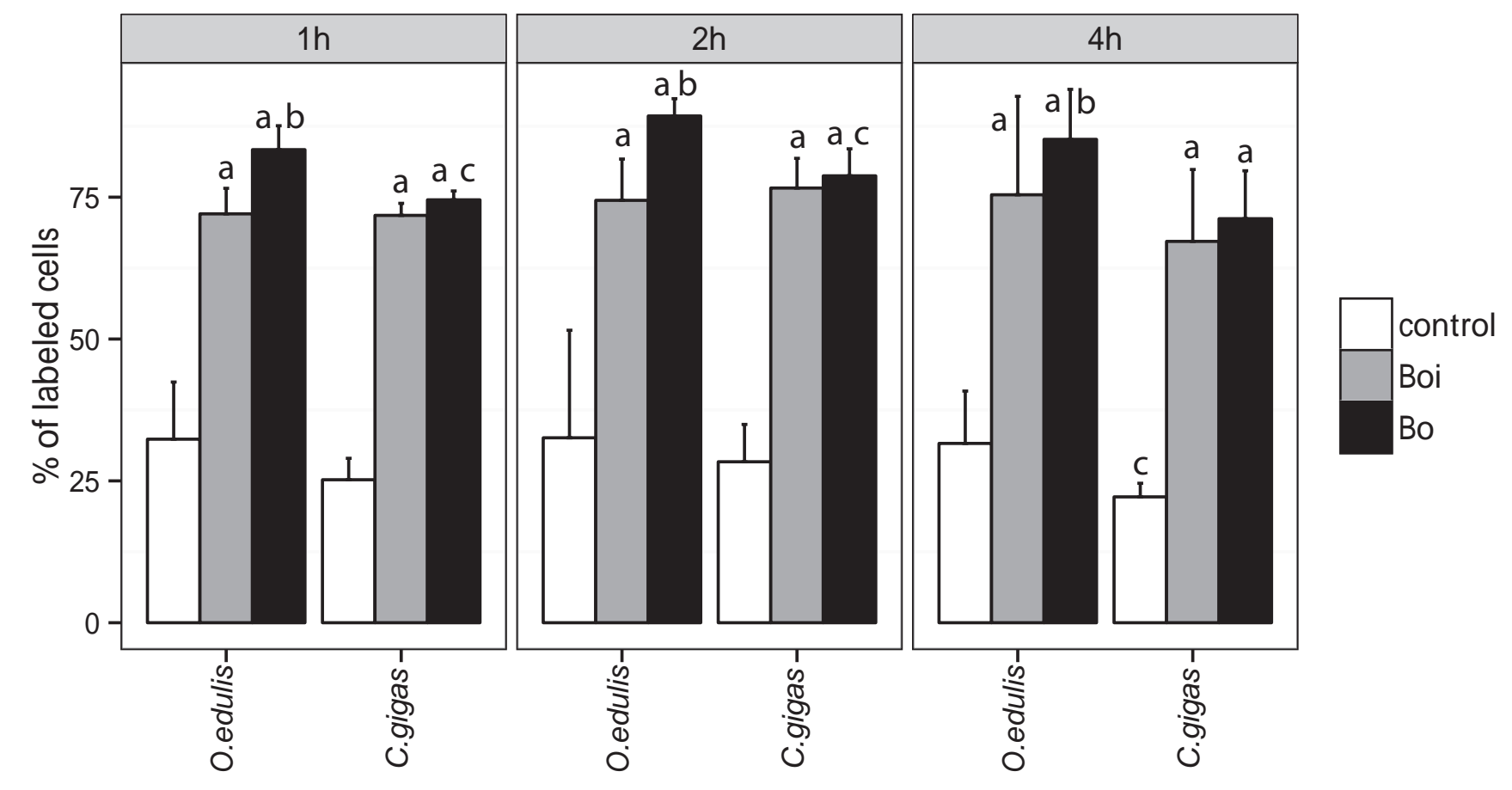




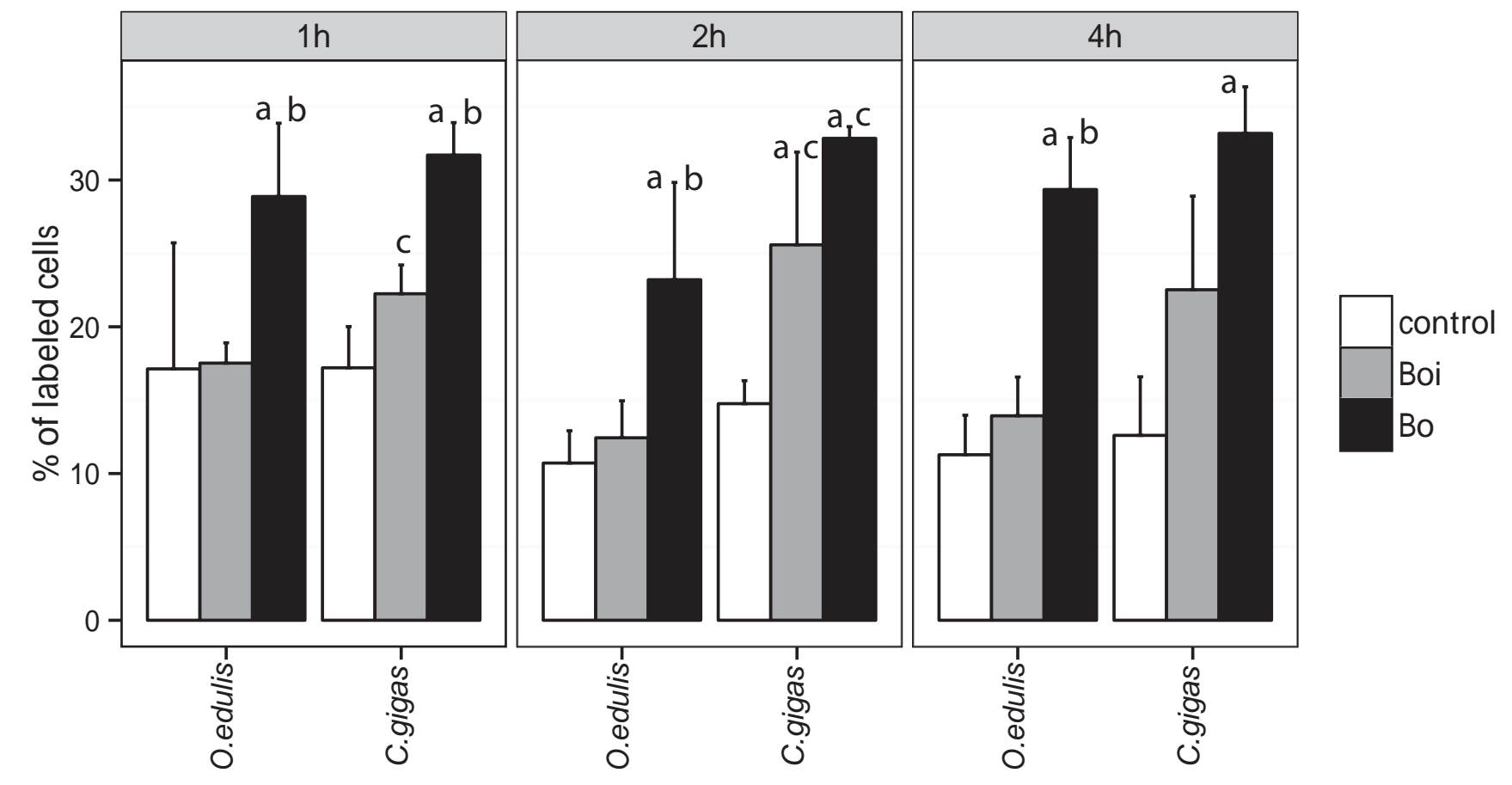




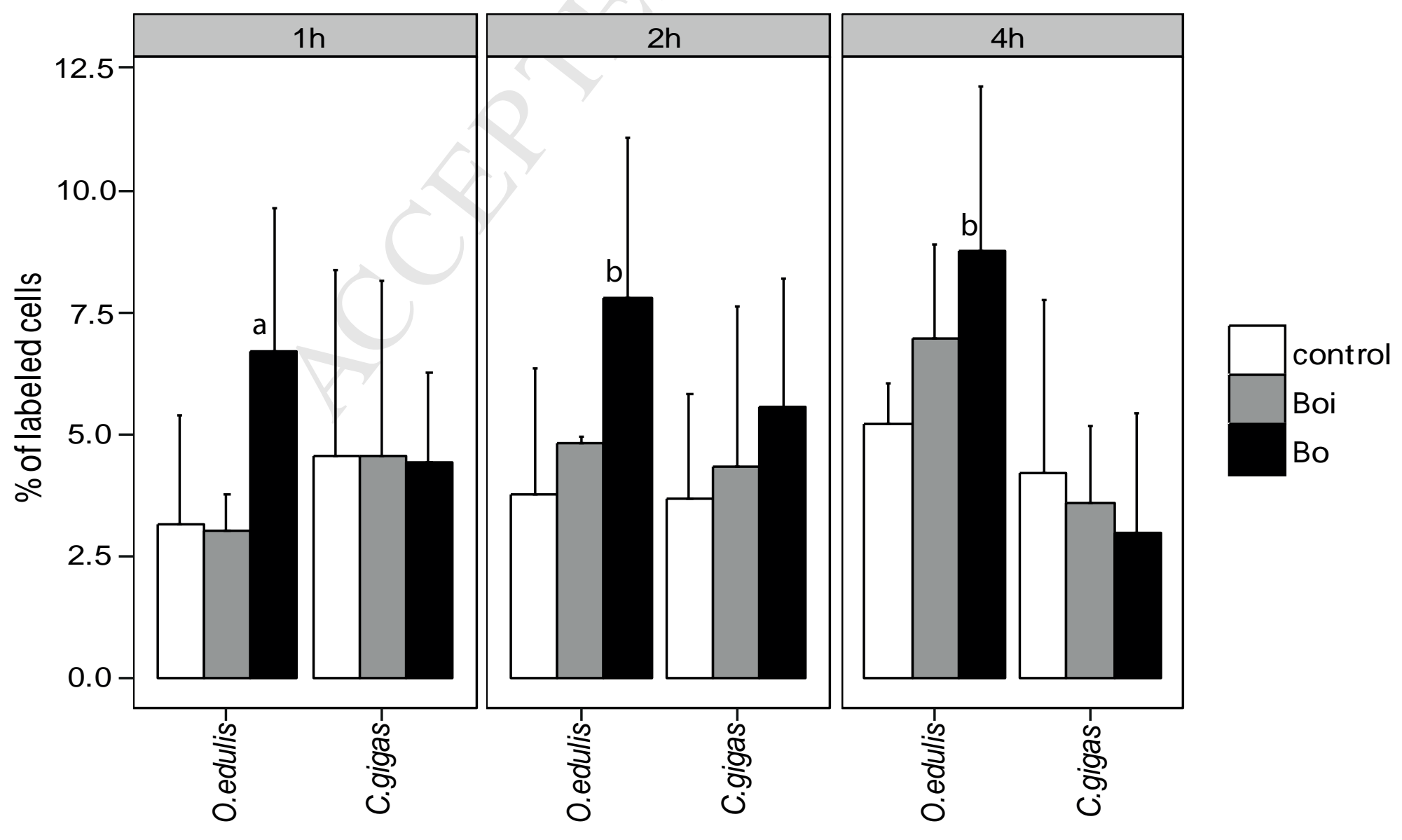




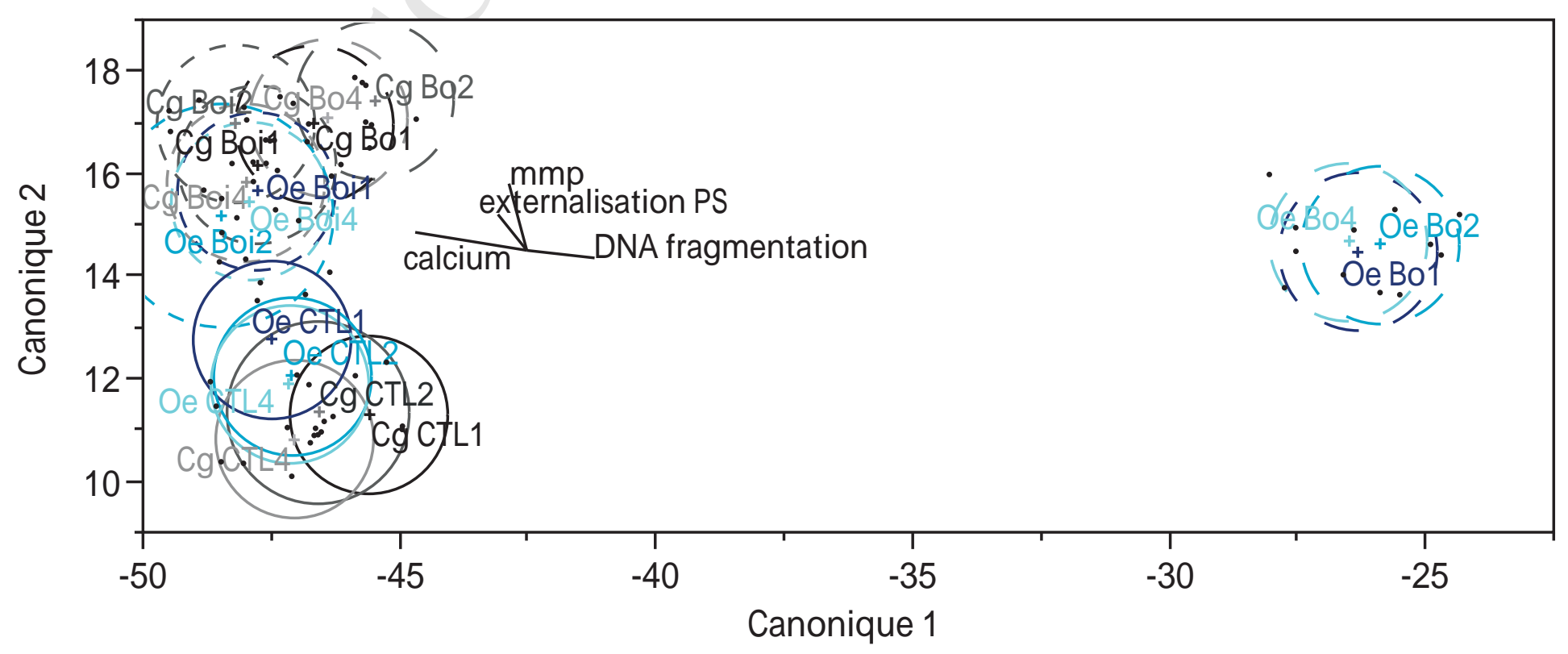




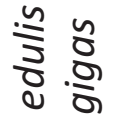

variable 1 variable $2 \stackrel{0}{0}$ نु

internalization calcium $\square$

internalization $\Delta \Psi \mathrm{m}$

internalization annexin $\quad-0,2$

internalization TUNEL $\quad 0$

calcium annexin $\quad 0,2$

$\begin{array}{ll}\text { calcium } & \Delta \Psi \mathrm{m}\end{array}$

calcium TUNEL $\quad 0,6$

$\Delta \Psi_{\mathrm{m}} \quad$ annexin

$\Delta \Psi_{\mathrm{m}} \quad$ TUNEL

annexin TUNEL 


\section{ACCEPTED MANUSCRIPT}

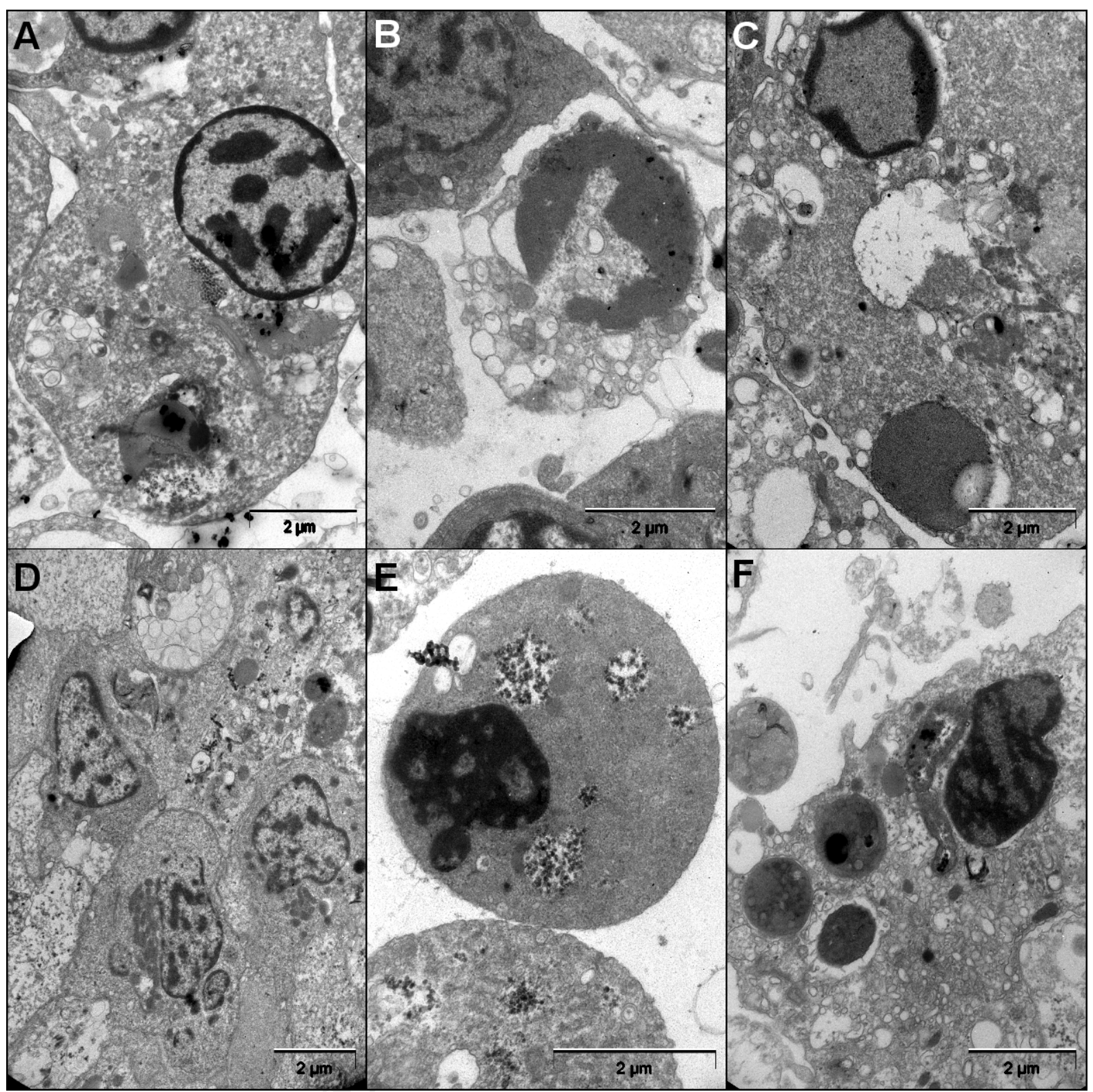

